\title{
Multimodality Analysis in President Joko Widodo's Video Blog
}

\author{
Febyola Oktavanya \\ Communication Management \\ Universitas Indonesia \\ Jakarta, Indonesia \\ febyolaom@gmail.com
}

\begin{abstract}
Youtube is an emerging new media whose popularity is rising not only among people in the industry but also among nation leaders, one of which is President of Indonesia Joko Widodo. President Joko Widodo is one of the only three nation leaders that use Youtube as a tool to communicate to their subjects. The purpose of this research is to analyze the content and message of the videos. This research uses qualitative methods of multimodal analysis (systemic language function by Van Leuween). The analysis unit of this research is two videos on President Joko Widodo's YouTube Channel tagged with \#JKWVLOG hashtag. The research found that semiotic sources are structured to give the image of a committed leader, with a relaxed and populist communication style.
\end{abstract}

Keywords- Multimodality, President Joko Widodo, vlog, YouTube

\section{INTRODUCTION}

YouTube is the number one most popular social media in Indonesia with a total of 50 million users per month from a total of 146 million internet users in Indonesia [1]. Therefore, a new phenomenon emerged that spawned a product called a video blog or widely known as Vlog. Youtube users can produce content in the form of vlogs that can take the form of opinions, everyday stories, and tutorials.

YouTube's popularity has not been overlooked by President Joko Widodo, who is fondly called President Jokowi, now has a YouTube account launched since May 28, 2016. As of March 7, 2020, the account has uploaded 393 videos and has 1,900,000 followers. This YouTube account contains official government activities such as government news and visits, as well as presidential personal activities marked by \#JKWVLOG.

Interestingly, President Joko Widodo's YouTube account is the only head of state account in the world that is managed on a regular and structured basis. President Joko Widodo's YouTube account itself seems to be intended for a young audience or commonly called the millennial generation. For millennial, messages that are entertaining and light for consumption do tend to be more desirable [2].

Through YouTube, President Joko Widodo can build a good communication by showing his daily life in a YouTube account. YouTube allows everyone to be a creator and every viewer can give their participation through comments, likes, and shares. This technology is used by President Joko Widodo to communicate with his people.

It can be said that President Joko Widodo was the first Indonesian President to use YouTube as a tool to communicate with the public, by sharing his daily activities and providing a forum for the public to comment.

Thus, wherever the president is on duty, the public can watch through his YouTube channel, without having to adhere to time and space. The public can assess the expertise, attitudes, appearance and everything that is displayed by President Joko Widodo in his videos. The content and purpose of the vlog is very interesting to be further explored. Based on this, the main problem that will be the focus of this research is to find out the coordination of political messages and to observe what semiotic sources are presented by President Joko Widodo in \#JKWVLOG.

\section{RESEARCH METHOD}

This study uses a qualitative approach, which is a research procedure that produces descriptive data in the form of nonverbal or verbal from people and observable behavior. The qualitative method was chosen, because it was considered suitable with the research theme to be carried out, in which there will be a fairly detailed and in-depth description using the Multimodality analysis method.

Multimodality analysis is defined as the use of several semiotics modes in product design, or semiotic events in a simultaneous and in a certain way. These modes are combined to strengthen, complement, or be in a particular arrangement [3]. This analysis method is used because it covers all aspects, namely language, sound and images. Multimodality can also be understood as an analytical procedure that combines linguistic analysis tools and steps such as systemic functional linguistics or functional grammar, with analysis tools for understanding images, if the text is analyzed using two modes, namely verbal and image [4].

This relevant method is used to see the meaning of the communication event to be studied more comprehensively, because communication is not just the delivery of messages from the sender to the recipient, but there is the delivery of meaning contained in the message. According to Bezemer and Kress, meaning can be conveyed through various modes. Fashion is understood as a socially and culturally formed source for communicating meaning, including language, images, sounds, spaces and even colors [3].

In multimodality analysis tools, images and sounds are seen as having a "language" that can function as a communication tool and have meaning. Images can be treated like language because they have three metafunctions namely logical, interpersonal and textual [3] In this study, authors treat videos in vlogs as a language that realizes an ideational metafunction, namely how images represent experiences. The 
object in this case is called a represented participant, that is, as an object in the picture and can be either living or non-living objects.

In addition to objects or items in the picture, also known as interactive participants or "viewers" who enjoy the video [4]. The author looks at the relationship between objects in the video, audience, and video maker that will be analyzed through the details of the movements represented, perspective or angle of shooting, and shots to see social distances, as well as attitudes towards interactive participants. The third metaphy is textual, in which the author sees how images are arranged and presented to cause a certain impression. The composition of different compositions allows different textual meanings and information.

In addition, the color is also considered to have a certain meaning which is generally influenced by the situation and culture in which the color is used. Kress and Leeuwan argue that color is a semiotic mode, because color has and can be used to convey meaning [2]. This research is descriptive in nature, which describes in detail the semiotic modes available in President Joko Widodo's video blog, which consists of pieces of images, sound and text.

The conclusions of the study were compiled based on descriptions and interpretations that were supplemented by links between communication concepts in President Joko Widodo's video blog and how texts, images and sounds were interpreted. In describing programs or the participation of people who are not familiar with the program, this method can help present a qualitative profile of one or more "typical" cases [5]. The object or target examined in this study is the vlog that is on the \#JKWVLOG playlists which are videos in President Joko Widodo's YouTube account.

Based on the sampling selection criteria as explained in the previous paragraph, the author decides the selection of vlogs as follows:

\section{A. \#JKWVLOG The Birth of Two-Tailed Goats At The Bogor Palace}

This vlog tells the story of the birth of two goats in the Bogor Palace. The birth of two young goats increased the number of Palace pet goats to 10 . This video is unique because it "presents" the birth of a goat child in the palace environment which is rare and rarely done by the Head of State of the Republic of Indonesia so far. In addition, the vlog uploaded on March 13, 2017 also attracted public attention and has reached 1,144,999 views, liked by 42,000 netizens and received 4,635 comments (as of March 6, 2020).

\section{B. \#JKWVLOG Navigating Trans Papua With Motor Trail}

This vlog tells the story of President Joko Widodo's visit with the Indonesian Ministry of Public Works and Public Housing to review the Trans Papua project. In this vlog depicted that President Joko Widodo conducted an inspection by riding a trail motorbike.

This video is unique because it presents the development that is being carried out in Papua Province, where during the administration before President Joko Widodo, the construction of the Trans Papua road infrastructure had not yet been carried out. The vlog that was uploaded on May 24, 2017 has been watched as many as 612,382 times, received 16,000 likes and received 1,774 comments (as of March 6, 2020).
Data collection methods in this study were carried out by analyzing data in the form of shot to shot scenes in the \#JKWVLOG videos under study and sorting them based on different and significant scenes. In searching literature, the author collects relevant data from a variety of books and journals that discuss the meaning of communication messages built on the video blog and their relation to cultural, ideological and other issues contained therein.

Data analysis techniques in this study consisted of several stages. The first stage is identifying the semiotic modes in each vlog studied. Mode is "A socially and culturally shaped resource for making meaning." This source is not limited to language as a familiar and commonly used source, but can also be shown in pictures, sounds, spaces / spaces with which people convey messages and offer meaning.

Then in the second stage, the author identifies each mode into semiotic resources. The sources of semiotics in multimodality analysis function like grammar or grammar in analyzing "language". Kress emphasizes that semiotic sources continue to change [7]. This theoretical attitude provides people as sign makers who shape and combine semiotic sources to reflect their interests

\section{RESUlT AND DisCUSSION}

\section{A. \#JKWVLOG The Birth Of Two-Tailed Goats At The Bogor Palace}

The Interactional Analysis contained in this video can be seen from several remarks from President Joko Widodo expressing his happiness with the birth of his pet goats at the State Palace. There are a number of angle positions for video capture using more close shot and medium shot techniques.

The medium shot shows President Joko Widodo as a person who does not want to part far from his audience, while the selfie camera and close shot video shows President Joko Widodo's desire to be close and interact with his people. However, the angle camera from below shows that President Joko Widodo still has a higher position than his people. Textual elements in \#JKWVLOG can be seen in several scenes, namely in the first scene where President Joko Widodo corrects the position of the cell phone camera used to record a vlog, showing that President Joko Widodo is a represented participant who records himself several shots in his vlog.

Textual context can be seen in the animations and text shown in the video as in the vlog title "\#JKWVLOG Birth of Two-Tailed Goats" at the beginning accompanied by a blue background and in a simple animation in the scene changing scene quotation towards the end of the video depicting calm and cheerful music depicting the moment of birth of a goat.

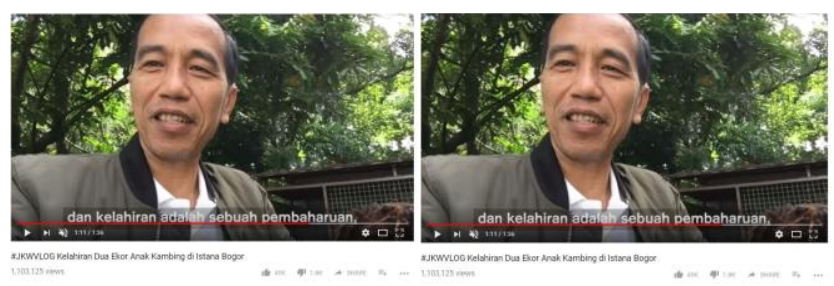

Fig. 1. Frame minutes 01.05 \#JKWVLOG The Birth Of Two-Tailed Goats At The Bogor Palace, source: Channel YouTube Joko Widodo.

This is a happy moment for President Joko Widodo and breaks the stigma that the figure of the President is considered 
as a leader who has a higher position compared to his people and has certain distances with his people.

\section{B. \#JKWVLOG Navigating Trans Papua With Motor Trail}

From the results of an ideational analysis, in the scene where President Joko Widodo and First Lady Iriana were welcomed by children in Papua who wore traditional clothes, there was interaction when he chatted and embraced the two Papuan children. From this analysis, it can be identified that President Joko Widodo is a humble President who mingles with his people in the midst of his busy life as President of the Republic of Indonesia.

From the results of the textual analysis, it is symbolized when President Joko Widodo and his entourage were driving along the Wamena lane to Kenyam and Agats which were under construction. In one shot where President Joko Widodo narrated in front of the camera, emphasizing the word "commitment", showed that he showed a figure of a leader who put forward the commitment to work for equitable infrastructure development, especially in Papua Province.

In the Interactional analysis on \#JKWVLOG, it shows the existence of high interpersonal elements and is shown in several video scenes. One example is when the scene of President Joko Widodo, who had arrived at the site of the visit and narrated in front of the camera, indicated a high degree of interactivity with his viewers.
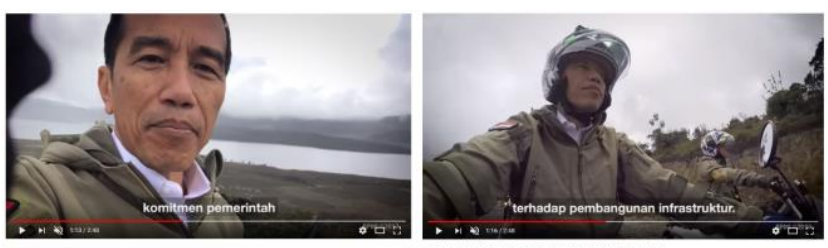

Fig. 2. Frame shot menit 1.07-1.18 pada \#JKWVLOG Menyusuri Trans Papua, source: Channel YouTube Joko Widodo

This shows that the presence of \#JKWVLOG which contains President Joko Widodo's visit to Papua indicates that he is a figure who cares about his country, prioritizing his commitment to realize the development of the State of Indonesia that is evenly distributed throughout the country.

\section{CONCLUSION}

Both of President Joko Widodo's vlogs contain semiotic sources which include body language, text, and artifacts. The sources of semiotics are arranged to provide an image of a committed leader, with a relaxed and populist communication style. It can be seen from non-verbal and verbal elements, such as gestures, views, body language to the choice of words spoken by the represented participant.

The textual element that President Jokowi wants to present has also given a new image to the country's leader through the clothes he is wearing. The image of the president who appeared more often wearing formal suits and ties was not shown in the video, therefore according to researchers, President Joko Widodo tried to break the old paradigm that was so deeply embedded in the minds of the public that the President could also appear like ordinary people.

The selection of the right content also helped President Joko Widodo be able to convey this motivation with light language and full of optimism. The vlog also portrays the figure of the President as an ideal leader seen from the work activities published by President Joko Widodo through his personal vlog.

\section{REFERENCES}

[1] Ayuwuragil, Kustin. Youtube Jadi Aplikasi Media Paling Populer di Indonesia. https://www.cnnindonesia.com/teknolo gi/20180406202852-213-288967/youtube-jadi-aplikasi-media-palingpopuler-di-indonesia, 2018.

[2] Jönsson, A., \& Örnebring, H. (2011). User-Generated Content and The News. Journalism Practice, 5(2), 127-144. DOI:https://doi.org/10.1080/17512786.2010.501155

[3] Kress, G. \& Van Leeuwen, T. (1996). Front Pages: (The Critical) Analysis of Kress, G. \& Van Leeuwen, T. (2001). Multimodal Discourse The Modes and Media of Contemporary Communication. Great Britain: Arnold.

[4] Hermawan, B. (2013). Multimodality: Menafsir Verbal, Membaca Gambar dan Memahami Teks. Jurnal Pendidikan Bahasa dan Sastra, 13(1), 19. DOI: http://dx.doi.org/10.17509/bs_jpbsp. v13il .756

[5] Patton, M. (2009). Metode Evaluasi Kualitatif (2nd ed.). Yogyakarta: Pustaka Pelajar.

[6] Kress, G. (2010). Multimodality. London: Routledge 